\title{
Governing (in)security in a postcolonial world: \\ Transnational entanglements and the worldliness of 'local' practice
}

Security Dialogue 43(5) 383-40I (C) The Author(s) 2012

Reprints and permission: sagepub. co.uk/journalsPermissions.nav DOI: $10.1177 / 0967010612458337$ sdi.sagepub.com @SAGE

\author{
Jana Hönke \\ Freie Universität Berlin, Germany
}

\section{Markus-Michael Müller}

Universität Leipzig, Germany

\begin{abstract}
While analysis of transnationalized forms of security governance in the contemporary postcolonial world features prominently in current debates within the field of security studies, most efforts to analyse and understand the relevant processes proceed from an unquestioned 'Western' perspective, thereby failing to consider the methodological and theoretical implications of governing (in)security under postcolonial conditions. This article seeks to address that lacuna by highlighting the entangled histories of (in)security governance in the (post)colonial world and by providing fresh theoretical and methodological perspective for a security studies research agenda sensitive to the implications of the postcolonial condition.
\end{abstract}

\section{Keywords}

security studies, security governance, postcoloniality, methodology, practice approaches, ethnography

\section{Introduction}

While there has been a growing interest in postcolonial approaches within the field of international relations as a way of moving beyond the limits and problems of dominant Western-centric approaches to global politics (see, for example, Hobson, 2012; Millenium, 2011; Chowdry and Nair, 2002; Slater, 2004; Ling, 2002; Paolini et al., 1999), this has been less visible within the subfield of security studies. When we consider that most of security studies' attention to (in)security in our contemporary world is inseparable from social and political developments in 'most of the world' (Chatterjee, 2004) - that is, the postcolonial world not just outside, but also within, the 'modern West' - and the resulting implications as well as the threats these developments are 
imagined to represent for global security and stability, this lack of interest is not just surprising; it also limits the explanatory and analytical potential of contemporary security studies. Most studies within the field depart from an unquestioned 'Western' perspective, assuming that long-cherished concepts, methods and theories that were developed in and against the empirical background of Western experiences can simply be applied to the analysis of the governance of (in)security 'abroad'. This leads to a highly biased form of knowledge production that, as has been pointed out in a paradigmatic way for international security studies, owing to its underlying Western-centrism is of 'arguably limited empirical and political relevance for major parts of the non-western world' (Buzan and Hansen, 2009: 19).

Of course, this is not to suggest that questions of postcoloniality have been completely ignored by security studies. In addition to the somewhat pioneering works of Ayoob (1995) on the 'third world security predicament', there have been a number of attempts to analyse the governance of (in)security under postcolonial conditions (e.g. Agathangelou and Ling, 2004; Krishna, 1999; Muppidi, 1999). And even some introductions to the field of critical security studies include sections on or chapter-long engagements with the broadly conceived issue of 'postcoloniality' (Peoples and Vaughan-Williams, 2010; Acharaya, 1997). However, such efforts have been of marginal interest to the various research agendas within security studies, and convincing calls for a 'postcolonial moment in security studies' (Barkawi and Laffey, 2006) have received remarkably little attention thus far. As a result, security studies continues to be haunted by a 'Western-centrism' that makes the knowledge production within the field parochial and peripheral, because it 'mistakes "Western" experiences for the universal, thus failing to take note of different insecurities and responses in other locales' (Bilgin, 2010: 619).

Addressing such shortcomings and problems stemming from the Western-centrism of security studies is the principal goal of this special issue of Security Dialogue. The central claim of the issue is that the notion of postcoloniality needs to be central to any such endeavour, as it helps us to critically engage with the entangled histories of transnational security governance from a de-exoticizing perspective that avoids essentialist practices of othering. Such a claim, however, should not be read as an uncritical call for homogenization that renders the thinking of difference impossible. Rather, the related challenge consists in taking differences and the 'exotic' seriously, in a way that critically interrogates the underlying relations of power and political purposes. This can be done by working with a 'strategic exoticism' that does not deny difference but avoids essentialization by challenging exoticist representational codes through an uncovering of the underlying differential (epistemological, political, symbolic, etc.) power relations (Huggan, 2001: 32).

For uncovering the entangled character of transnational fields of postcolonial (in)security governance from a de-exoticizing perspective, fresh theoretical and methodological approaches are needed - approaches that are suitable for and sensitive to the particularities of governing (in) security under postcolonial conditions and the related questions of local agency, processes of translation, appropriation and resistance. In this regard, this special issue calls for an empirical postcolonial security studies research agenda that moves beyond the predominant abstract thinking that dominates much of the related international relations scholarship, which, while correctly challenging the epistemological violence and blind spots of Western-centrism, remains overly situated at the level of macro-/meta-theoretical analysis. In our view, such a level of analysis provides little insight into a deeper understanding of how those transnational fields of security governance in our postcolonial world work 'on the ground'. Of course, this is not to deny the relevance of such studies, nor is this a plea a for a naïve 'theory vs empirical research' argument. Rather we follow Bourdieu's (1988: 774-5) dictum that 'theory without empirical content is empty, empirical research 
without theory is blind'. Therefore, all contributions to this special issue bring into productive dialogue both theory and empirical research - a dialogue that we consider to be essential for understanding and explaining transnational fields of security governance from a non-Western-centric perspective. For this endeavour, we also regard it as essential to work with empirical material that includes but goes beyond written text and includes everyday social practices, and this is another engagement that is shared by the contributions to this special issue.

Against this background, this introductory article will outline what we consider to be basic parameters for a postcolonial security studies research programme that focuses on the complex entanglements of transnational security governance as well as the involved interactions between 'local' and 'external' actors, practices and discourses. It describes a combination of theories and methods that we consider particularly useful for the analysis of those entanglements and interactions, and for moving beyond problems and blind spots within contemporary security studies scholarship on (in)security governance in our postcolonial world. In this endeavour, we seek to bring into productive dialogue propositions from neighbouring disciplines, area studies and critical security studies, and propose in particular three strategies: first, to identify new trans-local objects of research and to make concepts travel in various directions, which implies applying concepts that capture experiences in the postcolony to 'the West' (worlding); second, combining discourse approaches in the empirical research traditions of a Foucauldian analytics of governing with a methodological 'practice turn' that directs attention to competing rationalities of governing (in)security and to everyday forms of practice and local agency; and, third, to engage with interpretive political anthropology and use ethnographic methods.

Before turning to these issues, we wish to emphasize that while we are aware that some societies in our contemporary world were neither colonizing powers nor subject to colonialism (and imperialism), we nonetheless argue that even in those societies the governance of (in)security was affected by colonial encounters, most of all through processes of more or less 'voluntary' (and more or less selective) adaptations of globally dominant security knowledge, institutions (like prisons, police forces or 'modern' armies), technologies and practices that were themselves products of different colonial encounters, as the next paragraphs will show in greater detail.

\section{Entangled histories of (in)security and the postcolonial condition}

Before addressing the entangled histories of (in)security governance, it will be necessary to analytically differentiate between postcoloniality, or the postcolonial condition, and the notion of the postcolony. With the postcolonial condition, or postcoloniality, we refer to a global phenomenon of interactions based on unequal power relations in an era that goes beyond the world of colonialism but that has been (and continues to be) decisively shaped by the logic of coloniality (Mignolo, 2005: 69). In this regard, the notion of postcoloniality has a global analytical scope and stresses the legacies of colonial forms of rule, knowledge production and subjectification that continue to shape our contemporary world, where 'real' colonies have nearly ceased to exist (Hall, 1996; Gupta, 1998). While colonies have nearly disappeared, 'coloniality' and the underlying 'geopolitics of knowledge' can still be observed today (Mignolo, 2005). Postcoloniality thus designates situations of rule and subjectification that are based on 'us versus the inferior other' constructions and recourse to civilization and modernization discourses justifying asymmetrical interventions expressing 'the privilege of possessing dominant categories of thought from which and where the rest of the world can be described, understood, and "improved", (Mignolo, 2005: 36, emphasis in original). This Western "will to improve" ${ }^{11}$ is based on a particular polarized and hierarchical form 
of representation and knowledge production that Coronil (1996: 57) has called 'Occidentalism', which he defines as

the ensemble of representational practices that participate in the production of conceptions of the world which (1) separate the world's components into bounded units; (2) disaggregate their relational histories;

(3) turn difference into hierarchy; (4) naturalize these representations; and thus (5) intervene, however unwittingly, in the production of existing asymmetrical power relations.

Thinking about the postcolonial condition thus implies moving beyond the static analytics of 'bounded units' and fixed territorial spaces (such as 'the South' or particular taken-for-granted world regions) (Coronil, 1996; see also Mignolo, 2005). With the term 'postcolonial', we furthermore read colonialisms (of different kinds) 'as part of an essentially transnational and transcultural "global" process' (Hall, 1996: 247), shaping and reorganizing always entangled 'local' and 'global' power relations, even beyond those cases with histories of direct colonization - be that as colonizing or as colonized societies. The term therefore introduces a different reading of capitalist modernity, in that it emphasizes the centrality of entangled power/knowledge/practice fields through which unequal power relations emerge and are being transformed and challenged.

Compared to the global reach of the postcolonial, the analytical scope of the postcolony is more circumscribed. Typically, the postcolony has been defined as

nation states, including those from the former USSR, once governed by, for, and from elsewhere; nation states in which representative government and the rule of law, in their conventional Euro-modernist sense, were previously 'underdeveloped.' (Comaroff and Comaroff, 2006: 2-3)

Although there are different legacies and manifestations of (post)colonialism, it is possible to speak of structural factors and attributes common to postcolonies. These pertain to

a specific system of signs, a particular way of fabricating simulacra or re-forming stereotypes.... The postcolony is characterized by a distinctive style of political improvisation, by a tendency to excess and a lack of proportion as well as by distinctive ways in which identities are multiplied, transformed and put into circulation. But the postcolony is also made up of a series of corporate institutions, and a political machinery that, once in place, constitute a distinctive regime of violence. (Mbembe, 2001: 102-3)

While there is something particular about the postcolony, these particularities are not the product of isolated and 'endogenous' factors but rather stem from entangled histories, global encounters and uneven power relations. Taking such particularities seriously, furthermore, does not imply an 'othering' of the related experiences by claiming they are essentially different from those of the 'West'. Such 'difference' is, in fact, what the 'rest' was always expected to provide (Bilgin, 2009: 341) for the epistemic, academic and political self-imagination of the 'West', and in a moment we will introduce the idea of 'worlding' as a way of moving beyond such an essentializing understanding of difference. Before that, however, we propose a broadening of conventional understandings of the postcolony. While this notion is frequently used to refer to those spaces that became independent nation-states governed by the formerly colonized indigenous population, we argue that 'postcolonial relations' also characterizes the relationship between indigenous people and Creole elites, as, for example, in Latin America, as well as those between indigenous populations and the majority of the society in settler colonies inside 'the West', such as North America, Australia and 
New Zealand. In the latter cases, colonial settler societies that gained political independence continue to marginalize and discriminate against indigenous populations, inscribing postcolonial relations into liberal-democratic states that are marked by ongoing struggles over rights and recognition of indigenous groups (Grossman and Sparks, 2005; Johnson, 2011). Response to such struggles, as Crosby and Monaghan show in their contribution to this special issue, is inseparable from a form of 'settler governmentality'. This mode of governmentality, they demonstrate for the Canadian case, aims at eliminating indigenous practices through the deployment of managerial, coercive and legal technologies. Including settler societies into our understanding of the postcolony thus brings frequently neglected postcolonial power relationships within Western liberal democracies into a postcolonial security studies research programme.

Despite the previously made analytical distinction, the postcolonial and the postcolony are closely intertwined, both conceptually and politically. Obviously, postcolonies are privileged places of contemporary 'improvement' and civilizing missions. For moving beyond the Western-centrism that informs much of the related literature on these interventions, it is first of all important to sensitize security studies to the ways in which colonial and imperial encounters shaped the knowledge, institutions and practices involved in the governance of (in)security at home and abroad, thereby making visible the entangled transnational histories of postcolonial (in)security governance.

In this regard, scholarship on empires and colonialism has demonstrated how colonial territories and colonized people served as 'laboratories of modernity' (Stoler and Cooper, 1997: 5), where colonial powers experimented with and developed administrative practices, knowledge and technologies of rule that were subsequently 'reimported' back home. Even seemingly core ingredients of 'Western' disciplinary and surveillance power such as the panopticon were, contrary to commonly held wisdom, inventions of the colonial encounter (Mitchell, 1988: 35).

Similar developments, more directly related to the governance of (in)security, can be identified within the realm of policing. For example, the emergence in 1829 of the London Metropolitan Police, frequently referred to as the world's first 'modern' police force, was inseparable from knowledge production and practices regarding the governing of (in)security, political order, 'indigenous subjects' and 'dangerous classes' not only in the British colonies in North America, Africa and Asia, but also in Ireland (Williams, 2004; Brogden, 1987). This pattern of 'cross-fertilization' between colonial and domestic policing practices and knowledge continued to shape British policing ideas and practices throughout the 20th century (Sinclair and Williams, 2007). Of course, such entangled histories are not exclusively British. French policing, for instance, another seemingly 'classic' case of 'European' policing, emerged as 'an interactive process between the empire and mainland France', a process in and through which ideas of urban planning, as well as practices of legal and social control, permanently travelled back and forth between colony and metropole, thereby converting French colonies into 'laboratories for organized violence, where new forms of suppression, punishment, and political control were practiced and refined' (Thomas, 2011: xxii-xxiii). The continuing legacy of such encounters has been highlighted in McCoy's (2009) analysis of the entangled history of (post)colonial policing and state formation in the United States and the Philippines. His study showcases the crucial role of policing within the mutually reinforcing patterns of transnational (post)colonial state formation and the emergence of surveillance regimes and technologies in both countries from the beginning of the 20th century to the contemporary 'war on terror'.

These studies, while being sensitive to the unequal power relations that underpin (post)colonial entanglements, tell us that such encounters cannot be analysed as unidirectional processes in which 
seemingly all-powerful 'Western' actors and interests simply impose their will and 'domestic' institutions upon 'the rest'. Rather, they demonstrate that the actions of 'Western' actors are decisively shaped and transformed in and through (post)colonial entanglements and interactions. This also implies that seemingly subaltern actors can and do appropriate, and even 'refine', 'Western' security ideas, practices, institutions and discourses for their own interests. For instance, and in contrast to the longstanding exclusive focus on the central role of the United States in exporting counterinsurgency doctrines to Latin America throughout the 1960s, 1970s and 1980s, recent studies have demonstrated how Latin American security apparatuses themselves formed a transnational counterinsurgency network that appropriated and remodelled US (and French) counterinsurgency doctrines for their own practical needs and, as in the case of Argentina, exported their own knowledge and technologies of counterinsurgency to countries like Nicaragua, El Salvador, Guatemala and Honduras - in large part as a response to the 'alienating' foreign policy of the Carter administration and its human rights focus (Armony, 2008). In decentring, while not denying, the role of Western powers such as the United States, recent studies on state repression in Latin America also call for locating the 'local' histories of (transnational) (in)security practices and state terror 'within the region's broader colonial and postcolonial background and the formation of highly polarized societies based on class, race and ethnicity' (Esperanza, 2010: 3).

This argument has obvious relevance beyond the case of Latin America (for similar dynamics in Africa, see Clapham, 1996). And it calls attention to the internal repercussions of the previously mentioned (post)colonial encounters in modernity's 'laboratories of organized violence' themselves. As Ayoob (1995: 21) has convincingly argued, addressing this question most of all implies analysing (post)colonial state-formation processes. Throughout the history of colonialism and imperialism, the state itself - in other words, its technologies of rule and administration - was actively exported from the West (explicitly or, as in the case of countries like Thailand or Japan, implicitly through more or less forced processes of institutional adaptation) to societies in the Americas, Africa and Asia. Under the conditions of colonial rule, with its primary interest in economic exploitation and political stability, state institutions and functions that existed at home were frequently perceived as 'infeasible' for colonial subjects (Hansen, 2005: 174-7), mostly because many functions states exercised 'at home' were frequently considered to be unnecessary administrative, legal and 'welfare' baggage for the 'limited ambitions of the colonial state' (Herbst, 2000: 76).

As a result of this gradual process, and the controlling principle of colonial legislation and colonial subjects as permanently exempted and different from rule 'at home' in Europe, colonial sovereignties [and the colonial state itself] became (1) partial and provisional; (2) spectacular and yet ineffective in their exercise of territorial and social control; and (3) marked by excessive and random violence. (Hansen and Stepputat, 2005: 20)

The reference to the 'ineffective exercise of territorial and social control' points towards two aspects of central relevance for the question of (in)security governance in the postcolony. First, colonial powers themselves in many cases hardly had any interest in crafting something resembling their protection- and security-providing home states, endowed with a more or less wellestablished 'monopoly' of force. Operating with and under political logics that differed from, and were frequently contradictory to, those at home (Scott, 1995), the colonial security apparatuses, including institutions of social control and the administration of justice (and punishment), were marked by complex articulations between temporarily different political rationalities. These included 
the coexistence of public and spectacular violence exercised by the colonial state, 'traditional' forms of 'illiberal' punishment, and liberal, 'rational' and 'civilized' forms of security governance, which through their articulations created an uneven, contradictory and frequently quite fragile colonial 'mode of political normalization', indicative of the 'the halting and troubled career of the bio-political colonial state' (Rao and Pierce, 2006: 17).

Second, as a result of this, colonial security governance, protection and coercion-wielding were highly selective, privileging, in terms of protection as well as repression, places and populations that were of central economic and/or political importance for the maintenance of colonial rule and the reproduction of colonial power. This selectivity - largely out of fiscal, economic and political (including racial) reasoning - explains the widespread practice of 'outsourcing' political authority, coercion and repression to companies (Hönke, 2010, forthcoming) and to local intermediaries, the famous 'big men', ranging from the caciques in Latin America (Kern, 1973) to the zamidar landlords in India (Cohn, 2006), to 'traditional' chiefs in Africa (Mamdani, 1996), to name just some of the most prominent mediating local authorities. In addition to this, through their linguistic capabilities, native colonial bureaucrats and low-level employees were also frequently able to influence and transform the information, knowledge and actions of colonial powers, and to appropriate the symbols of the latter for their own purposes, thereby mediating colonial power and brokering between local elites and colonial officials (Osborn, 2003). The result of this situation has been the widespread 'rule of intermediaries' (Schlichte, 2005) throughout the (post)colony, the related informally negotiated character of political power (see, for example, Müller, 2012; Hagmann and Péclard, 2010), the presence of multiple forms of 'private indirect government' (Mbembe, 2001: 67-101), as well as the related dispersion of violence and fragmentation of sovereignty (Davis, 2010; see also Comaroff and Comaroff, 2006: 35).

Undeniably, the particular configuration of this 'fragmented sovereignty' (Davis, 2010) varies, as do the configuration of actors involved, the 'decentralized' nature of most postcolonial states (Krishna, 1999) and the negotiated character of the exercise of political power. Nonetheless, these structural aspects continue to shape the governance of (in)security in contemporary postcolonies, including the transnationalization of security governance, raising the question how such processes and developments can be investigated from a postcolonial perspective.

\section{Transnational (in)security governance through the lens of postcoloniality}

We claim that the point of departure for any research endeavour sensitive to the postcolonial condition of contemporary forms of transnational (in)security governance consists in what authors in other fields have called 'provincializing' (Chakrabarty, 2000) or 'decolonizing' (Rodríguez et al., 2010) security studies. This means avoiding practices of analytical othering by emphasizing the analytical 'limits of the European experience' (Wong, 1997). Seth (2009) contrasts two strategies in this regard: One consists in providing a different account of history through the lens of historical sociology. The other, informed by postcolonial theory, implies showing the limitations and non-universality of European analytical categories. While the latter tradition thus sensitizes us to the fact that 'the central categories of the social sciences are the product of a European history and are not necessarily adequate everywhere, even in their amended versions' (Seth, 2009: 336), historical sociology, according to Seth, can provide original accounts of subaltern or non-European history. Seth, however, is more in favour of the postcolonial approach and argues that non-Eurocentric historical sociology is mainly about "producing 
"better" knowledge on the grounds that it more accurately re-presents what really happened'. By missing the fact that knowledge is not only about re-presenting the world but also about creating it, historical sociology, according to Seth (2009: 336), tends to produce an external relationship between knowledge and object, a situation that, in contrast to postcolonial studies, the discipline seems incapable of overcoming.

In contrast to such a rather rigid juxtaposition, we think that taking historical sociology seriously is indispensable for a postcolonial security studies research programme, but that in order to unfold its anti-Western-centric potential, historical sociology, national as well as international, must engage more deeply with postcolonial studies. As Boatcă and Costa (2010:14) have argued in their call for a 'decolonized' sociology, it is through such an approximation between sociology and postcolonial studies that the epistemological limits of sociology that are the result of a particular academic and epistemological institutionalization of the discipline, and 'that so far have prevented the emergence of a global sociology of colonial, neocolonial and postcolonial contexts', can be overcome. It is such a 'decolonized' historical sociology through which 'historical contextualization as a postcolonial method' (Boatcă and Costa, 2010: 17) can be productively integrated into a postcolonial security studies research programme, ${ }^{2}$ by highlighting subaltern knowledge and entangled histories of non-Western societies. Decolonized historical sociology can also call our attention to phenomena that, while frequently considered to be occurring only beyond the West, characterize Western societies themselves, including, for example, areas hardly reached by the state and where the state's monopoly of force is absent or strongly compromised (e.g. marginalized urban spaces, such as the banlieues in France, ETA strongholds in Basque country, and urban and rural spaces controlled by the mafia in Italy or with forms of vigilante justice in the United States). Taking such insights seriously illustrates the limitations of analytical categories bound to the idea of a Western-centric methodological nationalism for understanding (in)security governance even in our contemporary world more generally.

Consequently, our critique of Western-centric analytical categories does not imply a call for abandoning all Western theory. Without denying that much, if not most, European theory is marked by the above-mentioned problems stemming from Occidentalism and Western-centrism, instead of simply abandoning these theories, we share Bhabha's (1994: 18-28) 'commitment to theory'. While challenging the 'fictitious universalism' (Bourdieu, 2000: 65) of Western theories, such a commitment, in our understanding, enhances their analytical scope through what Jackson, following Hall, called 'theoretical transculturation'. This implies 'demonstrating that such [Western] theory does not in fact describe or map the entire planet, and that despite pretensions to universalism it suffers from gaps and lacunae, and for this reason needs to be revised in the light of local empirical conditions' (Jackson, 2003: 73).

But the argument for provincializing security studies can even be pushed further. Writing from an African perspective, Mbembe and Nutall (2004: 348) argue that our task is not simply to demonstrate the fallacies of knowledge derived from a particular European experience, but rather to engage in a 'worlding' of the African experience. Africa is fraught as an idea and object of academic research, as it has become a sign in public debates for the 'other', the 'failed', the 'incomplete' and something apart from the world, probably more so than Latin America and Asia. Constructed as 'out of the world' by policymakers and academics, a postcolonial security studies perspective would require 'reinscribing' African (in)security knowledge, experiences and practices into the world and thereby depicting these as 'normal' and relevant parts of the human experience, not an exotic exception. This would imply recognizing the African experience of 'indeterminancy', 'provisionality', 'contingency' and uncertainty as 
a basic condition of life, and as a reality that requires analytical lenses and gives rise to relevant research questions in its own right (Mbembe and Nutall, 2004: 349). Recent scholarship in urban studies has not only stressed the 'ordinary' character of (postcolonial) urban experiences across the world (Robinson, 2006) but also suggests that postcolonial cities like Shanghai, Dubai or Lusaka, rather than Western cities, might be the avant-garde of global metropolitan developments (Myers, 2011; Roy and Ong, 2011) - including the governance of (in)security. Postcolonies might in fact offer 'privileged insight into the workings of the world at large' (Comaroff and Comaroff, 2012: 1). This calls for an engagement with sitespecific modernities and ways of constructing security governance in 'ex-centric sites' (Bhabha, 1994: 6) in the peripheries of world society in which the Western narrative of modernity is but one among others informing people's ways of imagining and constructing the world.

Taking such a perspective seriously produces new understandings of the dynamics of peacekeeping, state-building and anti-terror interventions - which security studies often deals with as though an innocent division could be drawn between interveners and intervened, a liberal 'us' and another 'them', or as though these interventions are the only privileged sites for the globalization of security knowledge and technologies in our contemporary world. However, security interventions also take place in indirect ways. Dominant (in)security discourses constitute situations and particular actors as transnational security risk, with important repercussions for individual security. A case in point is the 'discovery' of diaspora communities as partners in conflict prevention in 'developing countries', highlighted in Laffey and Sutharan's article in this issue with reference to the international engagement with the Tamil diaspora. Considering the above-mentioned entangled histories of (in)security governance, the analytics of postcoloniality also remind us that security practices are globalized through borrowing and emulation by local elites - be that through forced geopolitical pressures or as a result of instrumental calculation - as well as through indirect effects of hegemonic discourses and practices in transnational fields (Bilgin, 2010: 618; 2009: 340). Jacobsen's article in this issue on the introduction of the Unique Identity Number biometrical identification system for Indian citizens, which is inseparable from globally dominant discourses on technology, knowledge and development, is illustrative in this regard.

Postcoloniality pervades security knowledge and practices in all these spaces in which security governance is strongly shaped by external actors and/or transnational discourses and practice fields. However, few studies have looked into the de facto effects of these transnational influences on local (in)security governance and on the agency of those people involved and affected - both in and beyond the postcolony. Where such agency has been taken seriously, such efforts have mostly focused on the hybrid nature of the outcomes of external security interventions at the local level (e.g. Mac Ginty, 2010). By localizing the scope and effects of local agency to the local arena, such a perspective, however, downplays how 'local' agency and security practices may transform the transnational security field itself. While security studies has thus dealt with the transnational entanglements of (in)security governance in postcolonies and the 'local' repercussions of transnational security governance, much of the literature buys into the research objects, binary categories and unidirectional travelling of knowledge and institutions established in Eurocentric narratives of security governance. In the remainder of this article, we will therefore highlight three methodological moves that in our view provide the basis for overcoming these deficits and rendering security studies research more sensitive to the postcolonial condition. 


\section{New objects, travelling of concepts, a turn to practice and ethnography}

A first step for putting a sensitivity for the postcolonial condition into research practice in security studies would entail rethinking research objects in a way that digs out their 'invisible' translocal dimensions. It would also entail transferring research questions and analytical categories derived from the experiences in the postcolony to the West. In contrast to dominant one-way logics inherent in diffusion and transfer approaches, such a 'worlding' perspective acknowledges the pluri-directional circulation and effects of knowledge and practices in transnational fields. New objects of study in this sense revolve around the constitution of new political subjects of transnational (in)security governance, such as diasporas (see Laffey and Sutharan in this issue). Another area with innovative research in this regard is postcolonial urban studies, an inspiring research field for a postcolonial security studies research agenda. Scholars sensitive to the worldliness of postcolonial urbanity have started applying postcolonial approaches to the study of urban spaces within 'the West' that are often represented as 'other worlds' (Hentschel, 2011).

In addition to changing the direction in which research concepts travel, we see another promising avenue for decolonizing research on transnational security governance in moving analytical privilege from formal and highly institutionalized forms of transnational security governance to more subtle, non-official and little institutionalized forms, and to the interactions of the latter with the more institutionalized counterparts. New objects of research in this regard are, for instance, transnational functional fields such as the field of security professionals (Bigo, 2006; Leander, 2010; Abrahamsen and Williams, 2011). In addition to existing research on such security assemblages, which focuses on how these transnational fields work and affect specific localities in the postcolony, a postcolonial perspective calls for more attention to how they interact with competing social fields in specific localities and how they are (re)constructed and shaped by those interactions (see below). In his contribution to this special issue, Marc Duffield analyses the shift to resilience as a dominant logic for organizing aid work that occurred as a result of the contradictions between previous rationalities of aid and the competing expectations and forms of resistance aid workers were confronted with on the ground.

A second strategy consists in bottom-up research that engages with everyday forms of security practice, with competing rationalities of governing (in)security and with local agency. Existing literature within such a perspective in security studies revolves around the effects of transnational (in)security governance. Instead of looking at, for instance, risk management or surveillance practices in the postcolony per se-a top-down approach that might end up uncritically supporting the image of certain all-powerful governmental technologies - such work reconstructs de facto security practices that evolve around and parallel to particular security programmes and devices. For the case of security interventions and post-conflict management, it has been shown how Western governance technologies affect local politics in ways that contradict the official justifications for these very interventions. Related studies also go beyond stories of failure of external security interventions and demonstrate, for instance, how they (re) invigorate illiberal structures of indirect rule (Branch, 2011; Veit, 2010; Hönke, 2010). Adam Branch (2011) has shown, for instance, how human rights and security interventions in Northern Uganda produce counterproductive consequences, such as a perpetuation of conflict, local insecurity and inequality. The author traces these consequences back to the instrumentalization of external security interventions by local and external elites for political and economic interests, and to the depoliticizing nature of these interventions (see also Ferguson, 1990; Hönke, 2012). This approach builds on 'long-term commitment to place' that 'imposes empirical grounding 
and accountability on all abstractive practices that detach the elements of analysis from their antecedents and implications in people's radically different ongoing experiences in the world' (Guyer, 2004: 501).

While we appreciate such in-depth engagement with the de facto local effects of external security interventions and would hope for more such work, we suggest two promising avenues that would make it possible to go a step further in decolonizing security studies. The first consists in combining discourse approaches in the empirical research traditions of a Foucauldian analytics of governing with a methodological 'practice turn' that brings in sociological approaches, non-discursive practices and artefacts in the study of the governance of (in)security. Such discourse/practice-oriented methodologies should be exploited more decidedly for a postcolonial security studies research programme. The second avenue revolves around engaging with subaltern agency and the politics of translation, appropriation and resistance.

Concerning the first suggestion, key ingredients of the Foucauldian 'toolbox', notably discourse analysis and Foucault's work on governmentality, have already been prominently and productively included into postcolonial research (Nichols, 2010: 119) and related efforts by leading scholars as a way of successfully challenging Western-centric perspectives on Foucauldian grounds (e.g. Said, 1978; Bhabha, 1994; Stoler, 1995; Mbembe, 2001; Chatterjee, 2004, 2012). In security studies, efforts to combine the ingredients of the Foucauldian toolbox with practice approaches address, in our view, two major limitations in contemporary critical security studies and international relations scholarship. In particular, the Paris School of security studies and other work related to the broader project of a sociology of international relations highlight the power of practical knowledge beyond the study of text and (official) speech acts (Merlingen and Ostrauskaite, 2005; c.a.s.e. collective, 2006; Pospisil, 2009). However, this research still largely overemphasizes the study of hegemonic discourses and their practical effects, while neglecting other discourses and practices. The routines and procedures of security practitioners in UN interventions, for instance, might be shaped to some extent by dominant liberal political discourse. However, transferred across different postcolonial social worlds, the practical sense(s) of practitioners in everyday security governance is likely to diverge from this regulating 'macrological frame' (Gupta, 1998). In the implementation arenas of global security governance, different transnational meaning systems meet, collide and are reassembled (Hönke, forthcoming). Bringing in non-discursive practices thus not only makes it possible to move discourse-theoretical research beyond forms of 'armchair analyses' (Neumann, 2002: 628). It also helps to go beyond the 'programmers' view' (Dean, 2007: 83) and to identify such parallel or competing, often non-hegemonic, collective meaning systems that powerfully constitute local security practices.

As one of the present authors has shown in relation to the security practices of multinational companies in sub-Saharan Africa, the various actors involved in security governance are part of different, often incommensurable discourse and practice worlds that shape their sense-making of the world and eventually also their security practices (Hönke, forthcoming, 2012). Combining empirically oriented discourse theory with practice-oriented methods in such a context (Pouliot, 2007; Leander, 2010) allows for the appreciation of texture - common meaning structures that preconstitute agents' identities and choices - where discourse theory alone would probably not be able to see it. This brings into view heterogeneous 'low-status knowledge' (Valverde, 2003) and routine practices that are central for governing (in)security in transnational security fields. Such an approach can reveal changes in the rationalities of security governance even if these are not reflected in official speech, policies and programmes. It thus brings into view 'other' knowledge and social institutions constituting security agents' perceptions and choices in specific localities in the peripheries. While some of the perceptions and practices of security governance by company 
agents refer to the hegemonic liberal discourse of corporate social responsibility, the local engagement of companies is often far more complex and ambiguous than is generally admitted in the narrative of liberal governance and corporate social responsibility. Surveillance, deterrence, coercion and clientelistic practices are part of everyday security governance by these companies. Besides the diffusion of 'ethical business standards', corporate agents' security practices are thus also constituted in a commercialized global security field (Bigo, 2006; Leander, 2010) and a deeply rooted transnational practice community of a 'politics of the belly' (Bayart, 1993). The latter has evolved over at least the last 150 years between Western interveners and African polities, and revolves around providing personal rewards to authorities and political clients in exchange for stability (Hönke, forthcoming).

Instead of putting the blame for widespread failure of transnational security governance on deficits at the local level, this analysis of corporate security practices points to problems and contradictions within external security intervention that explain failure. The everyday security practices of company agents reflect the different discourses, fields and practice communities that are involved in these interventions. They produce heterogeneous security practices that compete, sometimes openly contest, and often merely coexist with those prescribed by expert knowledge and transnational formal institutions of security governance in various combinations, forming a heterogeneous 'regime of [security] practice' (Foucault, 1991: 75; see also Hönke, forthcoming).

However, such emphasis on the power of meaning systems should not be misinterpreted as a stance for a deterministic vision of agency in the postcolony. While we are convinced that agents are socially situated and their perceptions and choices constituted by collective meaning systems, there is of course room for agency and creativity in creating and (re)shaping (in)security governance under the condition of postcoloniality, and this brings us to the second research frontier within a practice- and agency-oriented approach to a postcolonial research programme. In order to reveal the pluri-directional circulation of knowledge and practices, research must analyse the concrete ways in which security knowledge and practices are created and used in a given transnational field. This overcomes a problem in international relations-oriented security studies that privileges the implementation of transnational policies and technologies originating from 'the West' elsewhere, without considering how these are locally understood, interpreted and transformed through practices of translation, appropriation and/or resistance.

Yet, external security interventions create new forms of politics among those subject to them. This translates into instrumental collaboration, resistance and various other forms of 'quiet encroachment' (Bayat, 2000). Therefore, interventions should be studied in a more humble way in relation to, among other factors, their impact on the complex 'politics of the governed' (Chatterjee, 2004 ) in the postcolony. Looking into processes of appropriation, translation and contestation of global models and their (subversive) transformation in transnational fields offers further insights into contemporary (in)security governance under the condition of postcoloniality (Müller, 2012: 124-50; Bachmann, 2010; Bachmann and Hönke, 2010; Richmond, 2010). More research should look into the agency of the governed (Hansson et al., forthcoming) by studying ways of translating, subverting or collectively resisting as well as actively shaping transnational security governance (see, for example, Scott, 1985; Merry, 2006; Rottenburg, 2009). Apart from visible collective action, the lens of postcoloniality directs attention to tacit forms of resistance and translation. In order to study forms of resistance that often go unnoticed, Michel de Certeau's (1984) understanding of subversion as a form of resistance proves useful. Subversion is not a form of resistance that rejects or tries to openly alter transnational security governance through collective action. Instead, the term refers to resistance through more or less discreetly using external security governance for different aims and purposes in the everyday. People might not be able to overcome a particular 
policy; often they might not even want to do so. However, they do have their ways of making a policy 'something quite different from what its authors intended' (Shore and Wright, 2011: 19). A postcolonial approach to external security governance and local agency also implies looking into the vernacularization of security governance through processes of translation. In our view, for such an endeavour - that of bringing the largely understudied aspect of the local agency of those who are addressed by and are part of transnational security governance in the postcolony into a postcolonial security studies research programme - a more thorough engagement of security studies with ethnography is apt.

The third methodological move we suggest here is thus a thorough engagement with ethnographic methods. While ethnography undeniably played an important part in the creation of occidental knowledge, recent scholarship has demonstrated the merits of this method for a postcolonial perspective (see, for example, Appadurai, 1996; Comaroff and Comaroff, 2003; Hansen and Stepputat, 2001). This implies, though, that engagement with ethnography needs to go beyond a positivist understanding of ethnography as another method of data collection (Vrasti, 2008). Within anthropology, in fact, the crisis of positivist representation has long been apparent (see, for example, Clifford and Marcus, 1986), and fieldwork, participant observation and interpretation are conducted in order to uncover systems of signification with great sensibility for reflexivity. Our call for interpretive ethnography and reflexivity therefore decisively implies more than 'going local', yet not necessarily an epistemological position that gives up on the possibility for intersubjectively understandable accounts of systems of representation. We rather contend with Wedeen (2010) that an interpretive understanding and use of ethnography does not preclude generalization. Rather, findings based on ethnographic research are particularly rich and empirically well-founded and can thus provide for better theories and useful generalizations than many of those based on statistical surveys, abstract formal models or secondary data that inform much contemporary security studies and international relations scholarship as a reflection of the hegemony of the "codeable" over the "messy" (Auyero and Mahler, 2011: 218) within these fields. Yet, a postcolonial methodology implies gleaning the meanings that the people we study attribute to their social and political reality, thereby teasing out emic perspectives and interpretations that are indispensable for understanding and explaining (in)security governance in the postcolony (see also Schatz, 2009). Interpretive ethnography in this sense asks us to keep in mind 'what agents think from', not only 'what agents think about'. It also reminds us to take into account our own 'writing from'. We do not refer to a place or identity in any essentialist sense in this regard, but to the socially constructed nature of social positions, perceptions and practices (Wedeen, 2009; see also Pouliot, 2007). This is apt in the field of security studies, in which objectivist truth claims tend to limit the use of ethnography in a way that ignores advances in anthropological methodology. More importantly in the context of our argument, importing such a limited version of ethnography risks reproducing dominant depictions of the 'other worlds' and therewith ignores, rather than fosters, the project of a postcolonial security studies.

Thus, as the Comaroffs have argued, if it avoids romanticizing ideas about 'naked' local truths, ethnography in a postcolonial world has a 'unique value in plumbing the nature and effects of largescale social, economic, and political processes' (Comaroff and Comaroff, 2003: 156) - including the emergence of transnational security fields. Such an endeavour is thus not bound to a single field site and 'indigenous' cultures, but can be employed to trace social worlds and practices in multiple sites of global security assemblages (Marcus, 1995; Shore and Wright, 2011). A postcolonial perspective thus also encourages using ethnographic methods to look at the social worlds powerfully constituting agents' practices within transnational security fields. Such sites include, for instance, the policymaking processes within which security interventions are planned. Such a perspective is offered by 
Stepputat's contribution to this special issue, in which he provides an auto-ethnography of knowledge production derived from the experience of writing a policy analysis for a Western government on 'concerted civil-military planning and action'.

\section{Looking ahead:Towards postcolonial security studies}

In this article, we have called for an empirical postcolonial security studies research programme. In discussing theoretical and methodological implications of such a perspective, we have highlighted the entangled nature of transnational security governance under postcolonial conditions and proposed three methodological strategies suitable for their analysis from a postcolonial perspective: identifying new research objects and 'worlding' the postcolonial experience; a theoretically trans-cultured combination of Foucauldian analytics of governing with practice approaches that pay attention to competing rationalities of governing security as well as to local agency; and an engagement with interpretive ethnography. While we do not claim that these moves are the only ways in which a decolonized security studies research agenda can be envisioned, we are nonetheless convinced that the proposed efforts provide essential building blocks for such an endeavour by challenging Western-centric approaches and research strategies that are detached from many empirical realities on the ground.

By productively engaging with one or more of the moves proposed in this introductory article, the articles that follow in this special issue, while not being exhaustive, illustrate the usefulness of a postcolonial perspective for understanding the complexities and ambivalences of transnational security governance in our contemporary postcolonial world. They point to some of the research frontiers we have suggested here and illustrate how the research programme we propose would close the identified gaps and/or create new insights on and theoretical understanding of how (in) security is governed. In this regard, rather than reading it as the first or ultimate statement on the dialogue between security studies and postcolonial thought, we hope that this special issue will stimulate and contribute to ongoing discussion, debate and critique in and through which a future comprehensive postcolonial security studies research programme becomes reality. In particular, we hope that bringing together innovative ideas from neighbouring disciplines (particularly anthropology), from area studies and from critical security studies will serve to bring forward the debate about the implications and strategies for critical empirical research that takes the postcolonial condition seriously - both within security studies and within the broader field of international relations. At the very least, that such a postcolonial perspective will be indispensable for moving beyond the prevailing Western-centrism in contemporary empirical security studies research will hopefully become beyond doubt for readers of this issue.

\section{Acknowledgements}

We would like to thank J. Peter Burgess, three anonymous reviewers and the participants of the ISA 2012 Panel on the special issue's theme for helpful comments on an earlier version of this paper. We are also thankful for the great discussion we had with the participants of the "Glocal" practices of security governance in the (post)colony' workshop we held in Berlin in 2010.

\section{Funding}

The "“Glocal” practices of security governance in the (post)colony' workshop was generously supported by the Research Centre SFB 700 Governance in Areas of Limited Statehood, financed by the German Research Foundation. 


\section{Notes}

1. This notion has been borrowed from Murray $\mathrm{Li}(2007)$.

2. See Hobson (2012) for a good example of such a decolonized international sociology.

\section{References}

Abrahamsen R and Williams MC (2011) Security Beyond the State: Security Privatization and International Politics. Cambridge: Cambridge University Press.

Acharaya A (1997) The periphery as the core: The third world and security studies. In: Krause K and Williams MC (eds) Critical Security Studies: Concepts and Cases. London: Routledge, 299-328.

Agathangelou AM and Ling LHM (2004) Power, borders, security, wealth: Lessons of violence and desire from September 11. International Studies Quarterly 48(3): 517-538.

Appadurai A (1996) Modernity at Large: Cultural Dimensions of Globalization. Minneapolis, MN: Minneapolis University Press.

Armony AC (2008) Transnationalizing the dirty war: Argentina in Central America. In: Gilbert MJ and Spenser D (eds) In from the Cold: Latin America's New Encounter with the Cold War. Durham, NC: Duke University Press, 134-168.

Auyero J and Mahler M (2011) Invisible connections and the making of collective violence. In: Polit Dueñas G and Rueda MH (eds) Meanings of Violence in Contemporary Latin America. Basingstoke: Palgrave Macmillan, 197-222.

Ayoob M (1995) The Third World Security Predicament: State Making, Regional Conflict, and the International System. Boulder, CO: Lynne Rienner.

Bachmann J (2010) Securitisation, Appropriation, Transformation? The Adaptability of International Counterterrorism Discourse and Practices in Kenya. PhD Thesis, University of Bristol.

Bachmann J and Hönke J (2010) 'Peace and security' as counterterrorism? Old and new liberal interventions and their social effects in Kenya. African Affairs 109(434): 97-114.

Barkawi T and Laffey M (2006) The postcolonial moment in security studies. Review of International Studies 32(2): 329-352.

Bayart JF (1993) The State in Africa: Politics of the Belly. London and New York: Longman.

Bayat A (2000) From 'dangerous classes' to 'quiet rebels': Politics of the urban subaltern in the global south. International Sociology 15(3): 533-557.

Bhabha HK (1994) The Location of Culture. London: Routledge.

Bigo D (2006) Globalized (in)security: The field and the ban-opticon. In: Bigo D and Tsoukala A (eds) Illiberal Practices in Liberal Regimes: The (In)Security Games. Paris: L'Harmattan, 5-49.

Bilgin P (2009) The international political 'sociology of a not so international discipline'. International Political Sociology 3(3): 338-342.

Bilgin P (2010) The 'Western-centrism' of security studies: 'Blind spot' or constitutive practice? Security Dialogue 41(6): 615-622.

Boatcă M and Costa S (2010) Postcolonial sociology: A research agenda. In: Rodriguez EG, Boatca M and Costa S (eds) Decolonizing European Sociology: Transdisciplinary Approaches. Farnham: Ashgate: 13-32.

Bourdieu P (1988) Vive la crise! For heterodoxy in social science. Theory \& Society 17(5): 773-787.

Bourdieu P (2000) Pascalian Mediations. Cambridge: Polity.

Branch A (2011) Displacing Human Rights: War and Intervention in Northern Uganda. Oxford: Oxford University Press.

Brogden M (1987) The emergence of policing: The colonial dimension. British Journal of Criminology 27(1): 4-14. Buzan B and Hansen L (2009) The Evolution of International Security Studies. Cambridge: Cambridge University Press. 
c.a.s.e. collective (2006) Critical approaches to security in Europe: A networked manifesto. Security Dialogue 37(4): 443-487.

Chakrabarty D (2000) Provincializing Europe: Postcolonial Thought and Historical Difference. Princeton, NJ: Princeton University Press.

Chatterjee P (2004) The Politics of the Governed: Reflections on Popular Politics in Most of the World. New York: Columbia University Press.

Chatterjee P (2012) Lineages of Political Society: Studies in Postcolonial Democracy. New York: Columbia University Press.

Chowdry G and Nair S (eds) (2002) Power and Postcolonialism in International Relations: Reading Race, Gender and Class. London: Routledge.

Clapham C (1996) Africa in the International System. Cambridge: Cambridge University Press.

Clifford J and Marcus GE (eds) (1986) Writing Culture: The Poetics and Politics of Ethnography. Berkeley and Los Angeles, CA: University of California Press.

Cohn B (2006) The Bernard Cohn Omnibus. Oxford: Oxford University Press.

Comaroff J and Comaroff J (2003) Ethnography on an awkward scale: Postcolonial anthropology and the violence of abstraction. Ethnography 4(2): 147-179.

Comaroff J and Comaroff J (2006) Law and disorder in the postcolony: An introduction. In: Comaroff J and Comaroff J (eds) Law and Disorder in the Postcolony. Chicago, IL: Chicago University Press, 1-56.

Comaroff J and Comaroff JL (2012) Theory from the South: Or, How Euro-America Is Evolving Toward Africa. Boulder, CO: Paradigm.

Coronil F (1996) Beyond Occidentalism: Toward nonimperial geohistorical categories. Cultural Anthropology 11(1): 51-87.

Davis DE (2010) Irregular armed forces, shifting patterns of commitment, and fragmented sovereignty in the developing world. Theory and Society 39(3-4): 397-413.

De Certeau M (1984) The Practice of Everyday Life. Berkeley, CA: University of California Press.

Dean M (2007) Governing Societies: Political Perspectives on Domestic and International Rule. Maidenhead: Open University Press.

Esperanza M (2010) Introduction: Globalizing Latin American studies of state violence and genocide. In: Esperanza M, Feierstein D and Huttenbach H (eds) State Violence and Genocide in Latin America: The Cold War Years. London: Routledge, 1-19.

Ferguson J (1990) The Anti-Politics Machine: 'Development', Depoliticization and Bureaucratic Power in Lesotho. Minneapolis, MN: University of Minnesota Press.

Foucault M (1991) Questions of method. In: Burchell G, Gordon C and Miller P (eds) The Foucault Effect: Studies in Governmentality. Chicago, IL: University of Chicago Press, 73-86.

Grossman M and Sparks C (2005) Unsettled states. Postcolonial Studies 8(3): 235-241.

Gupta A (1998) Postcolonial Development: Agriculture and the Making of Modern India. Durham, NC: Duke University Press.

Guyer JI (2004) Anthropology in area studies. Annual Review of Anthropology 33: 499-523.

Hagmann T and Péclard D (2010) Negotiating statehood: Dynamics of power and domination in Africa. Development and Change 41(4): 539-552.

Hall S (1996) When was the 'post-colonial'? Thinking at the limits. In: Chambers I and Curti L (eds) The Post-Colonial Question. London and New York: Routledge, 242-60.

Hansen TB (2005) Sovereigns beyond the state: On legality and authority. In: Hansen TB and Stepputat F (eds) Sovereign Bodies: Citizens, Migrants and States in the Postcolonial World. Princeton, NJ: Princeton University Press, 169-191.

Hansen TB and Stepputat F (2001) States of Imagination: Ethnographic Explorations of the Postcolonial State. Durham, NC: Duke University Press. 
Hansen TB and Stepputat F (2005) Introduction. In: Hansen TB and Stepputat F (eds) Sovereign Bodies: Citizens, Migrants and States in the Postcolonial World. Princeton, NJ: Princeton University Press, 1-38.

Hansson S, Hellberg S and Stern M (eds) (forthcoming) Studying the Agency of Being Governed. London: Routledge.

Hentschel C (2011) 'Postcolonizing Berlin: What can we learn from the Southern turn in urban studies when studying Berlin?' Unpublished manuscript, Berlin.

Herbst J (2000) States and Power in Africa: Comparative Lessons in Authority and Control. Princeton, NJ: Princeton University Press.

Hobson JM (2012) The Eurocentric Conception of World Politics: Western International Theory, 1760-2010. Cambridge: Cambridge University Press.

Hönke J (2010) New political topographies: Mining companies and indirect discharge in Southern Katanga (DRC). Politique Africaine 120: 105201327.

Hönke J (2012) Multinationals and security governance in the community: Participation, discipline and indirect rule. Journal of Intervention and Statebuilding 6(1): 89-105.

Hönke J (forthcoming) Transnational Companies and Security Governance: Securing Business Spaces. London: Routledge.

Huggan G (2001) The Postcolonial Exotic: Marketing the Margins. London: Routledge.

Jackson PA (2003) Mapping poststructuralism's borders: The case of poststructuralist area studies. SOJOURN 18(1): 42-88.

Johnson M (2011) Reconciliation, indigeneity, and postcolonial nationhood in settler states. Postcolonial Studies 14(2): 187-201.

Kern R (ed.) (1973) The Caciques: Oligarchical Politics and the System of Caciquismo in the Luso-Hispanic World. Albuquerque, NM: University of New Mexico Press.

Krishna S (1999) Postcolonial Insecurities: India, Sri Lanka, and the Question of Nationhood. Minnesota, MN: University of Minnesota Press.

Leander A (2010) Practices providing order: The private military/security business and global (in)security governance. In: Ougaard M and Leander A (eds) Business and Global Governance: Business in Global Governance. London: Routledge, 57-77.

Ling LHM (2002) Postcolonial international relations: Conquest and desire between Asia and the West. London: Palgrave Macmillan.

Mac Ginty R (2010) Hybrid peace: The interaction between top-down and bottom-up peace. Security Dialogue 41(4): 391-412.

McCoy AW (2009) Policing America's Empire: The United States, the Philippines, and the Rise of the Surveillance State. Madison, WI: University of Wisconsin Press.

Mamdani M (1996) Citizen and Subject: Contemporary Africa and the Legacy of Late Colonialism. Princeton, NJ: Princeton University Press.

Marcus GE (1995) Ethnography in/of the world system: The emergence of multi-sited ethnography. Annual Review of Anthropology 24: 95-117.

Mbembe A (2001) On the Postcolony. Berkeley, CA: University of California Press.

Mbembe A and Nutall S (2004) Writing the world from an African metropolis. Public Culture 16(3): 347-372.

Merlingen M and Ostrauskaite R (2005) Power/knowledge in international peacebuilding: The case of the EU Police Mission in Bosnia. Alternatives 30(3): 297-323.

Merry SE (2006) Human Rights and Gender Violence: Translating International Law into Local Justice. Chicago, IL: University of Chicago Press.

Mignolo W (2005) The Idea of Latin America. Malden, MA: Blackwell.

Millenium (2011) Special issue: Dialogue in international relations. Millenium 39(3): 607-803.

Mitchell T (1988) Colonising Egypt. Berkeley, CA: University of California Press. 
Müller MM (2012) Public Security in the Negotiated State: Policing in Latin America and Beyond. Basingstoke: Palgrave Macmillan.

Muppidi H (1999) Postcoloniality and the production of international insecurity: The persistent puzzle of U.S.-Indian relations. In: Weldes J, Laffey M, Gusterson H and Duvall R (eds) Cultures of Insecurity: States, Communities and the Production of Danger. Minnesota, MN: University of Minnesota Press, 119-146.

Murray Li T (2007) The Will To Improve: Governmentality, Development, and the Practice of Politics. Durham, NC: Duke University Press.

Myers G (2011) African Cities: Alternative Visions of Urban Theory and Practice. London: Zed.

Neumann IB (2002) Returning practice to the linguistic turn: The case of diplomacy. Millenium: Journal of International Studies 31(3): 627-651.

Nichols R (2010) Postcolonial studies and the discourse of Foucault: Survey of a field of a problematization. Foucault Studies 9: 111-144.

Osborn EL (2003) 'Circle of iron': African colonial employees and the interpretation of colonial rule in French West Africa. The Journal of African History 44(1): 29-50.

Paolini AJ, Elliott A and Moran A (eds) (1999) Navigating Modernity: Postcolonialism, Identity, and International Relations. Boulder, CO: Lynne Rienner.

Peoples C and Vaughan-Williams N (2010) Critical Security Studies: An Introduction. London: Routledge.

Pospisil J (2009) Die Entwicklung von Sicherheit: Entwicklungspolitische Programme der USA und Deutschlands im Grenzbereich zur Sicherheitspolitik [The Development of Security: Security-Related Development Policy Programmes of the USA and Germany]. Bielefeld: Transcript Verlag.

Pouliot V (2007) Subjectivism: Toward a constructivist methodology. International Studies Quarterly 51(2): 359-384.

Rao A and Pierce S (2006) Discipline and the other body: Humanitarianism, violence, and the colonial exception. In: Pierce S and Rao A (eds) Discipline and the Other Body: Correction, Corporeality, Colonialism. Durham, NC: Duke University Press, 1-35.

Richmond OP (2010) Resistance and the post-liberal peace. Millennium: Journal of International Studies 38(3): 665-692.

Robinson J (2006) Ordinary Cities: Between Modernity and Development. Abingdon: Routledge.

Rottenburg R (2009) Far-Fetched Facts: A Parable of Development Aid. Cambridge, MA: MIT Press.

Roy A and Ong A (eds) (2011) Worlding Cities. Malden, MA: Wiley-Blackwell.

Said E (1978) Orientalism. New York: Vintage.

Schatz E (ed.) (2009) Political Ethnography: What Immersion Contributes to the Study of Power. Chicago, IL \& London: University of Chicago Press.

Schlichte K (2005) Der Staat in der Weltgesellschaft. Politische Herrschaft in Asien, Afrika und Lateinamerika [The State in World Society: Political Domination in Asia, Africa, and Latin America]. Frankfurt: Suhrkamp.

Scott D (1995) Colonial governmentality. Social Text 43: 191-220.

Scott JC (1985) Weapons of the Weak: Everyday Forms of Peasant Resistance. New Haven, CT: Yale University Press.

Seth S (2009) Historical sociology and postcolonial theory: Two strategies for challenging Eurocentrism. International Political Sociology 3(3): 334-338.

Shore C and Wright S (2011) Conceptualising policy: Technologies of governance and the politics of visibility. In: Shore C, Wright S and Però D (eds) Policy Worlds: Anthropology and the Analysis of Contemporary Power. New York \& Oxford: Berghahn, 1-26. 
Sinclair G and Williams CA (2007) 'Home and away': The Cross-fertilisation between 'colonial' and 'British' policing, 1921-85. The Journal of Imperial and Commonwealth History 35(2): 221-238.

Slater D (2004) Geopolitics and the Post-Colonial: Rethinking North-South Relations. Malden, MA: Blackwell.

Stoler AL (1995) Race and the Education of Desire: Foucault's History of Sexuality and the Colonial Order of Things. Durham, NC: Duke University Press.

Stoler AL and Cooper F (1997) Between metropole and colony: Rethinking a research agenda. In: Stoler AL and Cooper F (eds) Tensions of Empire: Colonial Cultures in a Bourgeois World. Berkeley, CA: University of California Press, 1-58.

Thomas M (2011) Introduction: Mapping violence onto French colonial minds. In: Thomas M (ed.) The French Colonial Mind, Volume 2: Violence, Military Encounters, and Colonialism. Lincoln, NE: University of Nebraska Press, xi-liii.

Valverde M (2003) Law's Dream of a Common Knowledge. Princeton, NJ: Princeton University Press.

Veit A (2010) Intervention as Indirect Rule: Civil War and Statebuilding in the Democratic Republic of Congo. Frankfurt: Campus.

Vrasti W (2008) The strange case of ethnography in international relations. Millennium: Journal of International Studies 37(2): 279-301.

Wedeen L (2009) Ethnography as interpretive enterprise. In: Schatz E (ed.) Political Ethnography. Chicago, IL: University of Chicago Press, 75-94.

Wedeen L (2010) Reflections on ethnographic work in political science. Annual Review of Political Science 13: $255-272$.

Williams R (2004) A state of permanent exception. Interventions 5(3): 322-344.

Wong R B (1997) China Transformed: Historical Change and the Limits of European Experience. Ithaca, NY: Cornell University Press.

Markus-Michael Müller is a Senior Researcher at the Centre for Area Studies, Universität Leipzig. He is author of Public Security in the Negotiated State: Policing in Latin America and Beyond (Palgrave Macmillan, 2012), and his research focuses primarily on state formation and (in)security in Latin America.

Jana Hönke is a Researcher at the Research Centre SFB 700: Governance in Areas of Limited Statehood, Freie Universität Berlin. She is the author of Transnational Companies and Security Governance: A Practice Approach (Routledge, forthcoming) and co-director of a research project on business and governance in subSaharan Africa. Her research focuses primarily on (re)ordering processes and security practices beyond the state in international relations and in Africa. 